\title{
Applying the Analytic Hierarchy Process Decision Analysis to Better Understand Adoption Intentions of Mobile Banking
}

\author{
Wen-Tsung $\mathrm{Wu}$ \\ Department of International Business, National Dong-Hwa University \\ No. 1, Sec. 2, Da Hsueh Rd. Shoufeng, Hualien 97401, Taiwan \\ Tel: 886-3863-3042Ｅ-mail: 810232011@ems.ndhu.edu.tw \\ Chie-Bein Chen \\ Department of International Business, National Dong-Hwa University \\ No. 1, Sec. 2, Da Hsueh Rd. Shoufeng, Hualien 97401, Taiwan \\ Tel: 886-3863-3048Ｅ-mail: cbchen@ mail.ndhu.edu.tw

\begin{abstract}
Chiao-Chen Chang
Department of International Business, National Dong-Hwa University

No. 1, Sec. 2, Da Hsueh Rd. Shoufeng, Hualien 97401, Taiwan

Tel: 886-3863-3058Ｅ-mail: aka@mail.ndhu.edu.tw
\end{abstract}

Received: March 23, 2016 Accepted: April 17, 2016

doi:10.5296/ber.v6i1.9621

URL: http://dx.doi.org/10.5296/ber.v6i1.9621

\begin{abstract}
The purpose of this study was to examine the influencing factors of the adoption intention of mobile banking from a bank perspective. The survey data were conducted from a selection of mobile banking, and were analyzed by the analytic hierarchy process (AHP) decision analysis to explore adoption intentions in the context of mobile banking. The results of the AHP decision analysis revealed that the "convenience" and the "personalization" were the most important factors for mobile banking from a bank's perspective. Furthermore, the research findings illustrated theoretical and practical implications for mobile banking development and
\end{abstract}


indicated how to reinforce the "location-based benefits" and the "transaction speed" in order to create customer adoption intentions via a bank perspective.

Keywords: Analytic Hierarchy Process, Mobile Banking, Adoption Intentions

\section{Introduction}

Before the Internet banking era, traditional bank services constituted labor intensive activities, such as deposits, withdrawals, and transfers as well as foreign exchanges and trades at the stock exchange. Through Internet banking, the fixed costs in information technology (IT) investments have become relatively higher and the variable costs relatively lower (Atay \& Apak, 2013). The Internet has ushered in an IT-based revolution in the financial services sector that has radically altered the way that banking services are delivered (Hanafizadeh, Keating, \& Khedmatgozar, 2014). However, the global market for mobile entertainment goods and services grew from $\$ 17.3$ billion in 2006 to $\$ 76.9$ billion in 2011 . In recent years, worldwide mobile payment transaction values surpassed $\$ 171.5$ billion in 2012, marking a $61.9 \%$ increase from 2011 values of $\$ 105.9$ billion, according to Gartner, Inc. An analyst from Gartner also expected global mobile transaction volume and value to average $42 \%$ annual growth between 2011 and 2016 and forecasted a market worth $\$ 617$ billion with 448 million users by 2016 (Gartner, Inc., 2014). New mobile technologies such as mobile websites, smartphones, and tablets allow users and financial service providers to interact practically free of time or space constraints. As mobile phones are basically communication devices, they can be used for several other purposes, such as for executing financial or banking transactions. The technological deployment in banking services has changed the venue of selling and buying financial services. Therefore, banks can retain current banking users when offering a new system in existing systems and have an opportunity to convert mobile device users into banking users (Gu, Lee, \& Suh, 2009).

However, few studies have discussed the revisit intention of green hotels from hotel's perspective, this study fills this research gap to develop and test a research model to investigate the revisit intention of green hotels to better understand the context of green consumption.

\section{Literature Review}

\subsection{The Context of Mobile Banking}

Low costs, time savings, and autonomy at any time and any place (Karjaluoto, Mattila, \& Pento, 2002) have been found to be key elements of Internet banking. Some studies (e.g., Yao, Liu, \& Yuan, 2013) have focused on mobile banking because it can provide real-time services ubiquitously and reduce the operating costs. Mobile technologies and broadband are essential for mobile banking services, which are defined as a subset of e-banking performed in a wireless environment (Coursaris \& Hassanein, 2002). Certainly, mobile banking (also known as m-banking, SMS banking, etc.) is a form of banking transaction carried out via a mobile phone; it refers to banking and financial services carried out with the help of mobile telecommunication devices. Mobile banking can be seen as a subset of banking electronics and an extension of Internet banking with its own characteristics (Laukkanen \& Passanen, 
2008). It is also referred to as cell phone banking, which is "the use of mobile terminals such as cell phones and personal digital assistants (PDAs) to access banking networks via the wireless application protocol (WAP)" (Zhou, Lu, \& Wang, 2010, p. 760).

Indeed, mobile banking means that users adopt mobile terminals to access various payment services, such as account balance enquiry, transference, bill payment, and financial management (Zhou, 2012). Anderson (2010) noted that mobile banking has the potential to provide simple banking and electronic transaction services for non-banking customers in the development of markets. When a user obtains a registered account for mobile banking from the banking institution, the user could complete banking transactions from anywhere. Mobile banking can be done either by accessing the bank's website through the web browser on mobile devices or via text messaging. Mobile banking allows customers to perform three major transactions: (i) storing money in an account that is available via the mobile device; (ii) implementing cash-in and cash-out transactions with the stored account; and (iii) moving money among different accounts.

\subsection{Adoption Intentions}

Users of the Internet perform with motives that diverge from those associated with other existing technologies in that an information application (i.e. the Internet) involves the advent of new technology (Davis, 1989). To better predict adoption behavior, Tan and Teo (2000) integrated the diffusion of innovation theory and theory of planned behavior (TPB) to explain intention to adopt Internet banking. In the extended domain of mobile banking, Brown, Cajee, Davies and Stroebel (2003) applied Tan and Teo's (2000) Internet banking adoption framework to the mobile banking context.

\subsection{Critical Factors}

\subsubsection{Personalization}

Recent research has noted that personalization can be identified as devices, applications, and services that could customize the user's preference and comforts (Kim \& Ammeter, 2014). Furthermore, mobile banking can be personalized to indicate information or provide services in ways suitable to a specific user (Clarke, 2001). This performance can progress to a customer relationship management (CRM), thereby encouraging transactions while preventing users from switching to different services (Kuo \& Chen, 2006).

\subsubsection{Location-Based Benefits}

The ability to identify the customer's location at a sure time is one of the most promising applications of mobile commerce (Pura, 2005). In the mobile web environments, each service request submitted by a user can be associated with the current location acquired by positioning techniques like GPS embedded on mobile devices. The sequence of user requests forms a location-service stream, which this study refers to as the user's behavior patterns (Tseng \& Lin, 2006). However, Internet-based marketing lacks location specificity. Consequently, identifying the geographical position of a device (and, by implication, its user) is a distinctive characteristic provided by mobile banking. This gives e-banking service and 
content providers a chance to deliver localized information and services to users.

\subsubsection{Convenience}

Jayawardhena and Foley (2000) found that convenience offered via online banking is one of the factors influencing the acceptance of online banking. However, a positive relationship exists between convenience and service delivery via online banking, such as the ability of online banking to meet users' needs using the different feature availability of the services. Ramsay and Smith (1999) examined that convenience is one of the dominating factors in transaction channel preferences. Therefore, mobile banking provides a higher degree of convenience that enables customers to access financial services at all times and places.

\subsubsection{Transaction Speed}

Transaction speed (often referred to as response time) has received attention in the context of information systems and e-commerce due to an increase in focus on the efficiency of operational resources. Therefore, it is frequently discussed as an essential factor of satisfaction about information systems (DeLone \& McLean, 1992) or commercial website evaluations (Aladwani \& Palvia, 2002). Liao and Cheung (2002) argued that, in advanced societies, consumers tend to be highly sensitive to the speed of service delivery; thus, transaction speed, as a time-saving feature, is an essential consideration for customers' satisfaction with self-service technologies, such automated teller machines (ATMs), and is expected to have a positive influence on customer satisfaction with online banking.

\subsubsection{Information Content}

Content can be defined as the messages a website is trying to deliver or communicate to the user; it also refers to the information offered on the website. Contents play an important role in influencing consumers' behaviors. Tan and Teo (2000) used information content as one of the factors affecting the adoption of Internet banking. The key characteristics of a website can be categorized as either content or design (Huizingh, 2000). The information content of Internet banking can therefore have a positive influence on user adoption of mobile banking.

\subsubsection{Security}

Security and privacy are two important dimensions that might affect users' adoption of e based transaction systems (Poon, 2008). Some studies have also argued that security is an important determinant of online banking. Security refers to the reliability of Internet banking and users' overall belief that banking transactions can be completed confidentially and safely (Liao \& Cheung, 2008). As an extension to the mobile banking environment, security concerns play a critical role in mobile banking adoption (Wang \& Shan, 2013).

\subsubsection{Privacy}

Korgaonkar and Wolin (1999) found that non-transactional privacy concerns are significantly and negatively related to the percentage of business use on the Web. Consumers might not be willing to stake information about themselves due to their concern for privacy online, which is extended to mobile banking apps usage. 


\section{Macrothink}

\subsubsection{Design}

Design is essential to human-computer interaction (HCI) because it influences user satisfaction and task performance when using a computer (Palmer, 2002). Good website design enhances its usability, thereby affecting the website's success. Hence, this study infers that the design of the mobile banking apps might also have a positive influence on the adoption intention of mobile banking apps.

\section{Method}

\subsection{Research Framework}

This study focuses on the critical factors of adoption of mobile banking: personalization, location-based, convenient, transaction speed, information content, security, privacy, and design. The conceptual framework is presented in Figure 1.

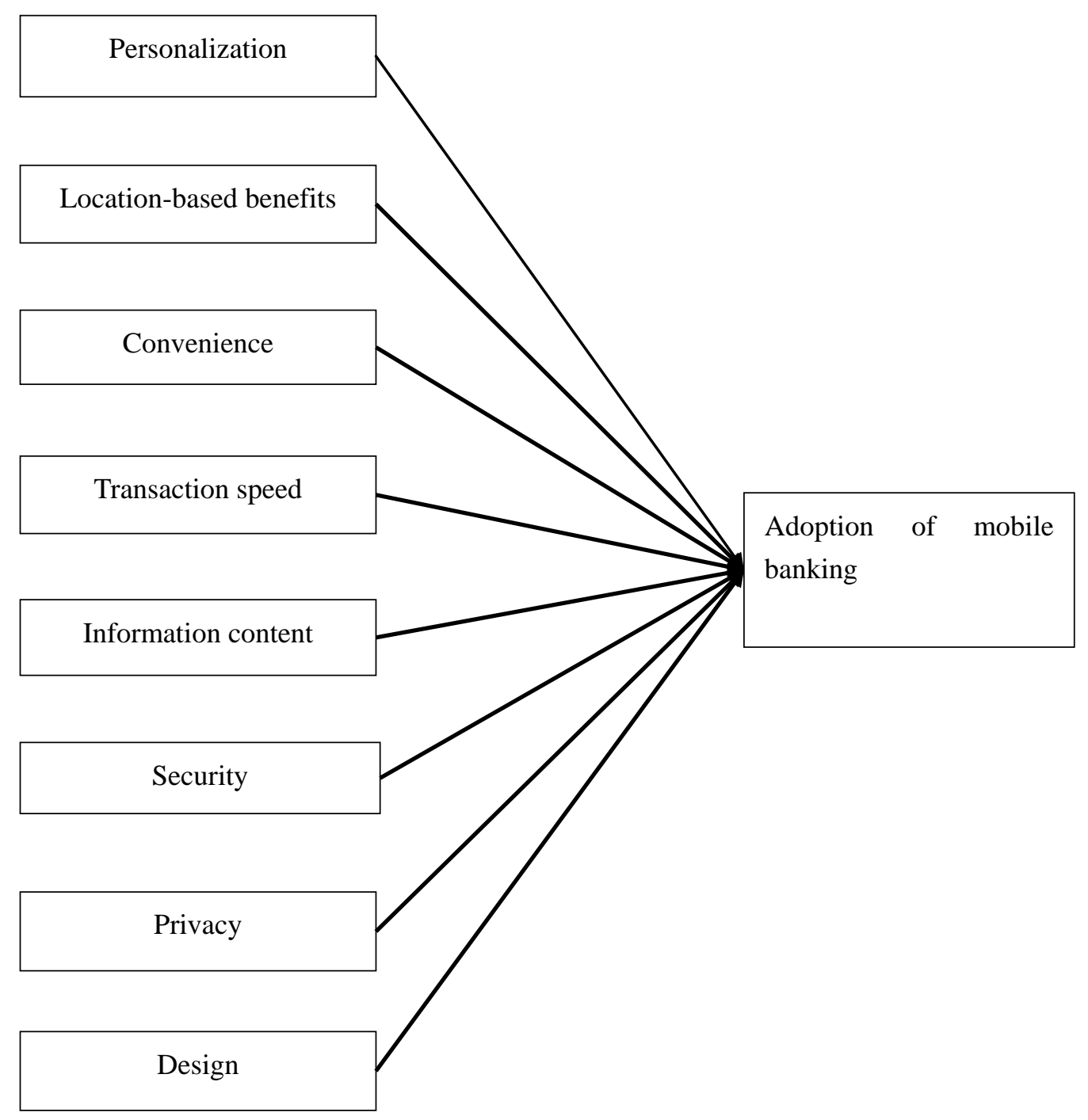

Figure 1. Research Framework 


\subsection{Questionnaire Design}

In discussing the decision factors of the adoption of mobile banking, the decision factors and priorities of banks were gathered from the previous research (Figure1). Pairwise comparisons were then made to compare the factors in pairs against a given criteria. The pairwise comparison scale was as follows: 1 for equal importance, 3 for the weak importance of one over another, 5 for essentials or strong importance, 7 for demonstrated importance, 9 for absolute importance, and 2, 4, 6, 8 for intermediate values between the two adjacent judgments (Saaty, 1980).

\subsection{Data Collection}

The questionnaire was administered. This study randomly selected three or four mobile banks from each type. Mobile banking questionnaires were sent to 15 mobile banks around Taiwan.

\section{Results}

\subsection{Sample description}

A questionnaire was divided into two parts. For the hotel experts, the questionnaire was sent during the period of January $1^{\text {st }}$, 2016 through January 20, 2016. 15 surveys were distributed and 13 were validated, yielding a response rate of $86.67 \%$.

\section{Analytic Hierarchy Process Analysis}

The principal eigenvalue $\lambda_{\max }$ is used to calculate the consistency of judgments. This study should obtain the weight $(w)$ of each row before calculating the $\lambda_{\max }$. The consistency index (C.I.) is used to examine whether the comparison matrix is consistent or not:

C.I. $=\frac{\lambda_{\max }-n}{n-1}$, where: $n$ is the element number and $\lambda_{\max }>n$ always. A C.I. $=0$ means that the judgment is completely consistent; if C.I. > 0, the judgment is not completely consistent; if C.I. $\leq 0.1$, the inconsistency of the matrix is at a tolerable level. C.R. $=\frac{C . I .}{R . I .}$ if C.R. $\leq$ 0.1 ; this means the consistency of the matrix is high.

The results of this study are as follows:

C.I. $=0.1296 \fallingdotseq 0.1$, and C.R. $=\frac{0.1296}{1.23}=0.1054 \fallingdotseq 0.1$

C.I. and C.R. are both $\leq 0.1$, meaning the consistency of the matrix is acceptable.

The most important factor is convenience $(\mathbf{0 . 4 2 1 3})$. This factor illustrates that mobile banking plays a very important role in providing efficient information of bank services. 


\section{Macrothink Institute ${ }^{T M}$}

The second most important factor is the personalization $(\mathbf{0 . 2 6 6 0})$. This factor means that mobile banking can provide personal information for each customer in order to satisfy their needs and wants.

The next four most important factors are: location-based benefits $(0.2003)$, transaction speed (0.1982), information content (0.1647) and design (0.0799). These results indicate that, on the practical aspect, location-based services, stable transaction speed, efficient service content, and effective design are the most visible and direct ways of providing mobile banking services.

Finally, the two factors with the lowest weight are: security $(0.0175)$ and privacy (0.0106). This implies that mobile banking does not want to spend too much on improving the implementation of security and privacy.

\section{Conclusions}

\subsection{Theoretical Implications}

This study makes three contributions to the literature in terms of understanding mobile banking. The first contribution of this study is the addition of new knowledge to our understanding of the critical factors of adoption of mobile banking. This study provides empirical support for a mobile banking index and standards with an analytic hierarchy process (AHP) that is not currently found in the previous literature. The AHP demonstrates the rank of all of the critical factors in order to better understand their importance. This is a new breakthrough for assisting with the development of mobile banking.

The contribution is made by extending the existing knowledge into a new context, the value perspective in the mobile commerce, previously only found in products (e.g., Koller, Floh, \& Zauner, 2011).

\section{Limitations and Opportunities for Future Research}

The findings and contributions of our study are, to some extent, constrained by certain limitations, some of which provide opportunities for future research. First, this study selected Taiwanese mobile banks as the research sample. Future research may choose other countries with mobile banking services as a research sample to make more convincing conclusions.

Second, owing to the limitations of time and the difficulty of obtaining research samples, we only measured the revisiting intentions towards green hotels. Hence, future research may consider exploring the actual behavior of revisiting the green hotel to examine whether the results are consistent or not.

\section{References}

Atay, E., \& Apak, S. (2013). An Overview of GDP and Internet Banking Relations in the European Union versus China. Procedia - Social and Behavioral Sciences, 99(6), 36-45. http://dx.doi.org/10.1016/j.sbspro.2013.10.469

Aladwani, A. M., \& Palvia, P. C. (2002). Developing and Validating an Instrument for 
Measuring User-perceived Web Quality. Information \& Management, 39(6), 467-476. http://dx.doi.org/10.1016/S0378-7206(01)00113-6

Coursaris, C., \& Hassanein, K. (2002). Understanding M-Commerce-a Consumer Centric Model. Quarterly Journal of Electronic Commerce, 3(3), 247-271.

Davis, F. D. (1989). Perceived Usefulness, Perceived Ease of Use, and User Acceptance of Information Technologies. MIS Quarterly, 13(3), 319-340. http://dx.doi.org/10.2307/249008

Gartner, Inc. (2014). Forecast: Mobile Payment, Worldwide, 2009-2016. Available at https://www.gartner.com/doc/2010515/forecast-mobile-payment-worldwide-/.

Gu, J.-C., Lee, S.-C., \& Suh, Y.-H. (2009). Determinants of Behavioral Intention to Mobile Banking. Expert Systems with Applications, 36(9), 11605-11616. http://dx.doi.org/10.1016/j.eswa.2009.03.024

Hanafizadeh, P., Keating, B. W., \& Khedmatgozar, H. R. (2014). A Systematic Review of Internet Banking Adoption. Telematics and Informatics, 31(3), 492-510. http://dx.doi.org/10.1016/j.tele.2013.04.003

Huizingh, E. (2000). The Content and Design of Web Sites: An Empirical Study. Information \& Management, 37(3), 123-134. http://dx.doi.org/10.1016/S0378-7206(99)00044-0

Karjaluoto, H., Mattila, M., \& Pento, T. (2002). Electronic Banking in Finland: Consumer Beliefs and Reactions to a New Delivery Channel. Journal of Financial Services Marketing, 6(4), 346-361. http://dx.doi.org/10.1057/palgrave.fsm.4770064

Koller, M., Floh, A., \& Zauner, A. (2011). Further Insights into Perceived Value and Consumer Loyalty: A “green" Perspective. Psychology \& Marketing, 28(12), 1154-1176. http://dx.doi.org/10.1002/mar.20432

Korgaonkar, P. K. \& Wolin, L. D. (1999). A Multivariate Analysis of Web Usage. Journal of Advertising Research, 39(2), 53-68.

Laukkanen, T. \& Pasanen, M. (2008). Mobile Banking Innovators and Early Adopters: How They Differ from Other Online Users? Journal of Financial Services Marketing, 13, 86-94. http://dx.doi.org/10.1057/palgrave.fsm.4760077

Liao, Z. \& Cheung, M. T. (2002). Internet-based E-Banking and Consumer Attitudes: An Empirical Study. Information \& Management, 39(4), 283-295. http://dx.doi.org/10.1016/S0378-7206(01)00097-0

Palmer, J. W. (2002). Web Site Usability, Design, and Performance Metrics. Information Systems Research, 13(2), 151-167. http://dx.doi.org/10.1287/isre.13.2.151.88

Poon, W.-C. (2008). Users' Adoption of E - Banking Services: The Malaysian Perspective. Journal of Business \& Industrial Marketing, 23(1), 59-69. http://dx.doi.org/10.1108/08858620810841498

Saaty, T. L. (1980). The Analytic Hierarchy Process. New York: McGraw Hill. International. 
Tan, M., \& Teo, T. S. H. (2000). Factors Influencing the Adoption of Internet Banking, Journal of the Association for Information Systems, 1(1), 1-42.

Wang, B., \& Shan, C. (2013). The Effect of Online-to-Mobile Trust Transfer on the Foundation of Mobile Banking Trust. Communications and Network, 5, 112-115. http://dx.doi.org/10.4236/cn.2013.51B025

Yao, H., Liu, S., \& Yuan, Y. (2013). A Study of User Adoption Factors of Mobile Banking Services Based on the Trust and Distrust Perspective. International Business and Management, 6(2), 9-14.

Zhou, T. (2012). Understanding Users' Initial Trust in Mobile Banking: An Elaboration Likelihood Perspective. Computers in Human Behavior, 28(4), 1518-1525. http://dx.doi.org/10.1016/j.chb.2012.03.021

Zhou, T., Lu, Y., \& Wang, B. (2010). Integrating TTF and UTAUT to Explain Mobile Banking User Adoption. Computers in Human Behavior, 26(4), 760-767. http://dx.doi.org/10.1016/j.chb.2010.01.013

\section{Copyright Disclaimer}

Copyright for this article is retained by the author(s), with first publication rights granted to the journal.

This is an open-access article distributed under the terms and conditions of the Creative Commons Attribution license (http://creativecommons.org/licenses/by/3.0/). 